Вашай Ю. В. [1; ORCID ID: 0000-0002-0664-0485], к.е.н., доцент,

Дорошенко О. О. [1; ORCID ID: 0000-0002-6428-0326], к.е.н., доцент

\title{
СТРУКТУРУВАННЯ ЕКОНОМІЧНОЇ БЕЗПЕКИ ДЕРЖАВИ В УМОВАХ ВІЙСЬКОВО-ПОЛІТИЧНОЇ НЕСТАБІЛЬНОСТІ
}

Статтю присвячено розгляду варіантів структури економічної безпеки. Авторами проаналізовані складові економічної безпеки держави, що регламентовані нормативними документами України, а також ті, що виділяють у своїх працях науковці. Розглянуто підходи до структурування економічної безпеки за елементами, за функціями, за джерелами виникнення загроз, за сторонами економічних процесів. Авторами запропоновано у складі зовнішньої підсистеми економічної безпеки виділити військову, зважаючи на значний вплив військових подій на економічний стан держави. Зазначено, що починаючи із анексії Криму, розгортання гібридної війни на Донбасі, економічна безпека України перейшла із антикризової в безпеку в умовах військових конфліктів, тому вже неможливо відділяти економічну безпеку від військової. Автори дійшли висновку, що кожна складова має велику значимість і заслуговує окремих досліджень. Однак ці дослідження слід проводити системно, вивчаючи взаємні впливи між складовими економічної безпеки, а також між іншими складовими національної безпеки держави у сучасному глобалізованому та військово нестабільному середовищі.

Ключові слова: економічна безпека; військова безпека; національні інтереси; загрози; військово-політична нестабільність.

Актуальність теми. Військово-політична нестабільність в Україні, що існує впродовж останніх років, призводить до того, що на перший план виходять питання дотримання національної безпеки. У iï складі не існує другорядних складових, оскільки їх комплексна взаємодія посилює загальний ефект. У таких умовах гібридної війни та систематичного виникнення глобальних та внутрішніх загроз важливе значення мають правильні та вчасні управлінські рішення в сфері економічної безпеки. Вони мають ґрунтуватись на результатах фундаментального аналізу економічних процесів і науковій основі предмету та об'єктів економічної безпеки держави. 
Аналіз останніх досліджень і публікацій. У зв'язку із значною актуальністю проблематики економічної безпеки на різних рівнях суб'єктів господарювання, питання дослідження іï структури розглядаються багатьма вітчизняними дослідниками. Значний внесок у розвиток теорії економічної безпеки здійснили такі вчені, як І. Бінько, 3. Варналій, М. Єрмошенко, Я. Жаліло, В. Кириленко, В. Мунтіян, Г. Пастернак-Таранушенко, В. Предборський, І.Ревак, А. Сухоруков, В. Шлемко та ін. Сучасні підходи до теорії і практики розглядаються В працях таких науковців, як С.Давиденко, О. Єгорова, В. Приходько, С. Козловський, Є. Жураківський, Р. Яковенко, Х. Сігова, Р. Пустовійт, Т. Кваша, Р. Волощук та ін. При цьому питання розширеного наукового аналізу структурування економічної безпеки з метою їі подальшої оцінки та ідентифікації загроз не втрачають актуальності у зв'язку із постійною зміною зовнішніх та внутрішніх політично-економічних умов, що сприяють виникненню потреб систематичного перегляду методичних основ оцінки економічної безпеки.

Метою статті $\epsilon$ визначення сучасної структури економічної безпеки держави згідно з різними аспектами їі виміру в сучасних умовах військово-політичної нестабільності.

Викладення основного матеріалу. Зважаючи на те, що економічна безпека $є$ складною системою, яка має свою структуру, її дослідження слід проводити у розрізі окремих складових. Складовими економічної безпеки відповідно до Методичних рекомендацій щодо розрахунку рівня економічної безпеки України [2] $\epsilon$ : макроекономічна, продовольча, фінансова, зовнішньоекономічна, інвестиційно-інноваційна, енергетична, виробнича, демографічна, соціальна, продовольча безпека.

Аналіз підходів вчених до виділення складових економічної безпеки дає змогу зробити висновок, що практично всі вчені серед таких складових виділяють фінансову, науково-технологічну, енергетичну, демографічну, соціальну, продовольчу, воєнну.

Геєць В. М. до складових безпеки реального сектору економіки включає такі складові: техніко-виробничу, енергетичну, технологічну, воєнно-економічну, продовольчу безпеку [3, С. 492496].

Погоджуючись із таким складом, все ж зауважимо, що воєнна безпека - це настільки специфічна сфера, що включення її до складу економічної зводить їі роль до економічних питань. Воєнна безпека включає комплекс складових, пов'язаних з обороноздатністю країни та їі захищеністю від зовнішніх та внутрішніх військових атак і 
безперечно багато в чому залежить від рівня фінансування та торкається численних економічних питань. Проте вважаємо їі самостійною важливою складовою національної безпеки, відокремленою від економічної, проте тісно з нею пов'язаною.

Інший підхід до структури економічної безпеки пов'язаний із виконанням нею певних функцій, зокрема захисної, регуляторної, попереджувальної, інноваційної та соціальної. Ці функції фактично узгоджуються із самою дефініцією поняття «економічна безпека» (рис. 1).

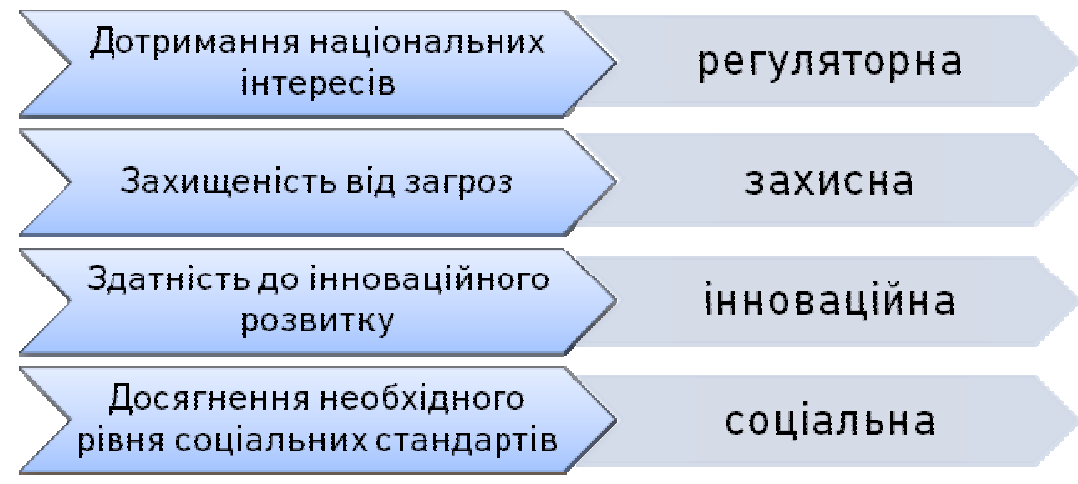

Рис. 1. Узгодження дефініції поняття «економічна безпека» із функціями, що вона виконує

*Розроблено авторами

В економічній літературі система безпеки держави представлена внутрішніми та зовнішніми підсистемами (табл. 1), які мають свої складові: фінансова;

- зовнішня підсистема безпеки - технологічна, комерційна,

- внутрішня підсистема безпеки - технічна та виробнича, харчова та сировинна, енергетична, екологічна, інформаційна [4].

Таблиця 1

Підсистеми економічної безпеки держави

\begin{tabular}{|c|c|c|}
\hline Підсистема & $\begin{array}{c}\text { Елементи } \\
\text { підсистеми }\end{array}$ & Визначення \\
\hline Зовнішня & Технологічна & 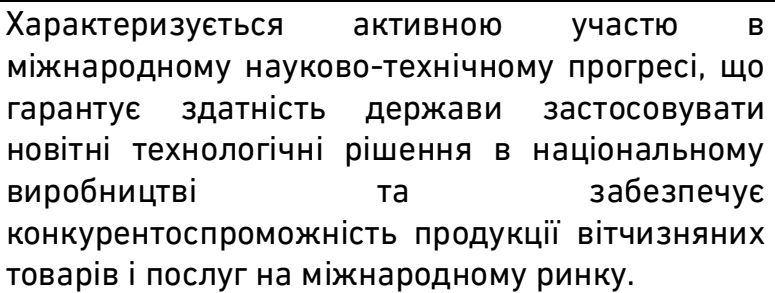 \\
\hline
\end{tabular}


продовження табл. 1

\begin{tabular}{|c|c|c|}
\hline & Комерційна & $\begin{array}{llr}\text { Є компонентом, що узагальнюе } & \text { стан } \\
\text { диверсифікації структури } & \text { експортної } \\
\text { імпортної торгівлі країни. } & & \\
\end{array}$ \\
\hline & Фінансова & $\begin{array}{l}\text { Здатність країни здійснювати незалежну } \\
\text { грошово-кредитну політику та забезпечувати } \\
\text { стабільне функціонування фінансової системи } \\
\text { шляхом повернення міжнародних позик і } \\
\text { отримання, розподілу, використання та } \\
\text { повернення іноземних інвестицій за наявності } \\
\text { несприятливих зовнішніх та внутрішніх умов. }\end{array}$ \\
\hline \multirow[t]{5}{*}{ Внутрішня } & $\begin{array}{l}\text { Технічна та } \\
\text { виробнича }\end{array}$ & $\begin{array}{l}\text { Складова, що забезпечує виробничі та технічні } \\
\text { можливості реалізації розширеного відтворення } \\
\text { економіки. }\end{array}$ \\
\hline & $\begin{array}{l}\text { Харчова та } \\
\text { сировинна }\end{array}$ & $\begin{array}{l}\text { Передбачає } \\
\text { необхідною } \\
\text { сирономічне зільстю продовольства та } \\
\text { сирови. }\end{array}$ \\
\hline & Енергетична & $\begin{array}{l}\text { Характеризує стабільне постачання достатньої } \\
\text { кількості необхідної енергії для внутрішнього } \\
\text { споживання. }\end{array}$ \\
\hline & Екологічна & $\begin{array}{l}\text { Здатність держави вчасно запобігти та усунути } \\
\text { розрив між суспільними інтересами та захистом } \\
\text { навколишнього середовища. }\end{array}$ \\
\hline & Інформаційна & $\begin{array}{l}\text { Передбачає таку економічну діяльність, } \\
\text { внаслідок якої гарантується надійність обміну } \\
\text { інформацією, збільшення } \\
\text { нематеріальних активів у частки } \\
\text { багатстві, а також конфіденційність технології } \\
\text { виробництва. }\end{array}$ \\
\hline
\end{tabular}

*Узагальнено авторами за [4]

Погоджуючись із таким підходом до структурування економічної безпеки, вважаємо за доцільне у складі зовнішньої підсистеми економічної безпеки виділити військову, зважаючи на значний вплив військових подій на економічний стан держави.

При акцентуванні на тих чи інших сторонах економічних процесів у країні, можна виділити цілу низку різновидів економічної безпеки:

- антикризову;

- в умовах мирного часу;

- в умовах військових конфліктів (різного масштабу) 3 використанням збройних сил;

- в умовах жорсткого економічного протистояння 3 певною державою;

- в умовах ізоляції або, навпаки, в умовах високого ступеня інтегрування у світову економіку [5]. 
До подій 2014 року питання економічної безпеки досить умовно перетинались із військовими аспектами. Починаючи із анексії Криму, розгортання гібридної війни на Донбасі, економічна безпека України перейшла із антикризової в безпеку в умовах військових конфліктів, тому вже неможливо відділяти економічну безпеку від військової.

Узагальнення підходів до елементів економічної безпеки держави дозволяє сформувати комплексне бачення ії структурування (рис. 2).

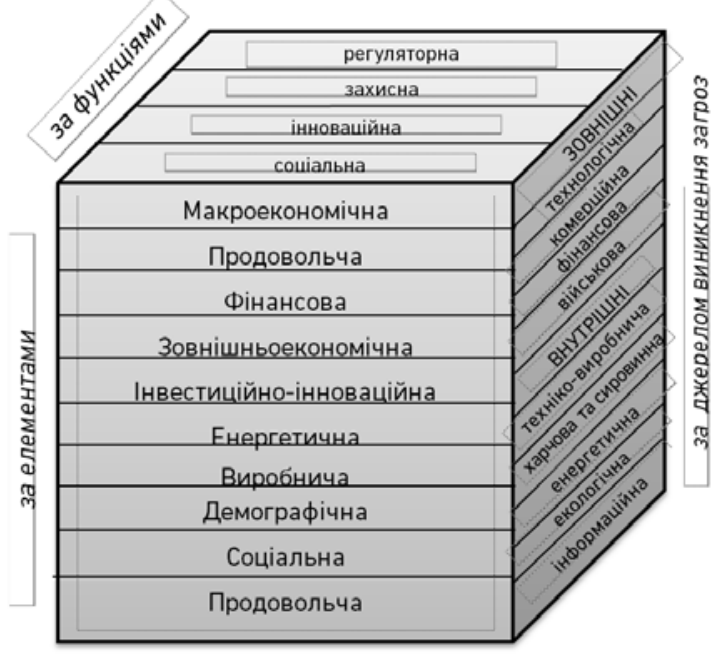

Рис. 2. Структура економічної безпеки держави узагальнено на підставі [4] та доповнено авторами

Висновки. Кожна складова має велику значимість і заслуговує окремих досліджень. Однак ці дослідження слід проводити системно, вивчаючи взаємні впливи між складовими економічної безпеки, а також між іншими складовими національної безпеки держави. У сучасному глобалізованому та військово нестабільному середовищі ці питання набувають особливої актуальності.

1. Кикель П. В., Сороко Э. М. Краткий энциклопедический словарь философских терминов. Минск: БГПУ, 2006. 266 с. 2. Про затвердження Методичних рекомендацій щодо розрахунку рівня економічної безпеки України: Наказ Міністерства економічного розвитку і торгівлі України № 1277 від 29.10.2013. URL: https://ips.ligazakon.net/document/view/ME131588 (дата звернення: 22.06.2020). 3. Перехідна економіка: підручник / Геєць В. М., Панченко Є. Г., Лібанова Е. М. та ін. К. : Вища шк., 2003. 591 с. 4. Tatul Melsik Mkrtchyan. State Economic Security System and Its Components. 4th Int'l Conference on Research in Humanities, Sociology \& Corporate Social Responsibility (RHSCSR'15) Sept. 25-26, 2015 Penang (Malaysia). URL: https://icehm.org/upload/3757ED915013.pdf (дата звернення: 22.06.2020). 5. Хвесик М. А., Степаненко А. В., Ральчук О. М., Дорош Й. М. Антикризове управління економічною безпекою в умовах викликів фінансово-економічної глобалізації (державний і регіональний виміри) : монографія. Київ, 2010. 309 с. 


\title{
REFERENCES:
}

1. Kikel P. V., Soroko E. M. Kratkiy entsiklopedicheskiy slovar filosofskih terminov. Minsk: BGPU, 2006. 266 s. 2. Pro zatverdzhennia Metodychnykh rekomendatsii shchodo rozrakhunku rivnia ekonomichnoi bezpeky Ukrainy : Nakaz Ministerstva ekonomichnoho rozvytku i torhivli Ukrainy № 1277 vid 29.10.2013. URL: https://ips.ligazakon.net/document/view/ME131588 (data zvernennia: 22.06.2020). 3. Perekhidna ekonomika : pidruchnyk / V. M. Heiets, Ye. H. Panchenko, E. M. Libanova ta in. K. : Vyshcha shk., 2003. 591 s. 4. Tatul Melsik Mkrtchyan. State Economic Security System and Its Components. 4th Intl Conference on Research in Humanities, Sociology \& Corporate Social Responsibility (RHSCSR15). Sept. 25-26, 2015 Penang (Malaysia). URL: https://icehm.org/upload/3757ED915013.pdf (data zvernennia: 22.06.2020). 5. Khvesyk M. A., Stepanenko A. V., Ralchuk 0. M., Dorosh Y. M. Antykryzove upravlinnia ekonomichnoiu bezpekoiu $v$ umovakh vyklykiv finansovoekonomichnoi hlobalizatsii (derzhavnyi i rehionalnyi vymiry) : monohrafiia. Kyiv, 2010. $309 \mathrm{~s}$.

\author{
Vashai Yu. V. [1; ORCID ID: 0000-0002-0664-0485] \\ Candidate of Economics (Ph.D.), Associate Professor \\ Doroshenko 0. 0. [1; ORCID ID: 0000-0002-6428-0326], \\ Candidate of Economics (Ph.D.), Associate Professor
}

${ }^{1}$ National University of Water and Environmental Engineering, Rivne

\section{STRUCTURING OF THE STATE ECONOMIC SECURITY IN THE CONDITIONS OF MILITARY AND POLITICAL INSTABILITY}

The article is devoted to the consideration of variants of the structure of economic security. The urgency of the topic is due to the fact that correct and timely management decisions in the field of economic security are important, when a country is in a hybrid war and the systematic emergence of global and internal threats. These decisions should be based on the results of a fundamental analysis of economic processes and the scientific basis of the subject and objects of the state economic security.

The purpose of the article is to determine the modern structure of the state economic security according to various aspects of its measurement in modern conditions of military-political instability. The authors analyze the components of economic security of the state, which are regulated by normative documents of Ukraine, as well as those identified by scientists in their work. Approaches to structuring economic security by elements, by functions, by sources of threats, by aspects of economic processes are considered. The authors propose to allocate military as part of the external subsystem of economic security, given the significant impact of military events on the economic condition of the state. It is noted that since the annexation of Crimea, the deployment of a hybrid war in the Donbass, Ukraine's economic security has moved from anti-crisis to security in military conflicts, so it is impossible to separate economic security from 
military. The authors concluded that each component is of great importance and deserves separate research. However, these studies should be conducted systematically, studying the interactions between the components of economic security, as well as between other components of national security. In today's globalized and militarily unstable environment, these issues become especially relevant.

Keywords: economic security; military security; national interests; threats; military-political instability.

Вашай Ю. В. [1; ORCID ID: 0000-0002-0664-0485], К.э.н., доцент,

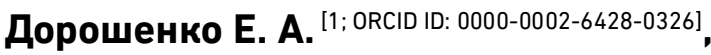
к.э.н., доцент

'Национальный университет водного хозяйства и природопользования, г. Ровно

\title{
СТРУКТУРИРОВАНИЕ ЭКОНОМИЧЕСКОЙ БЕЗОПАСНОСТИ ГОСУДАРСТВА В УСЛОВИЯХ ВОЕННО-ПОЛИТИЧЕСКОЙ НЕСТАБИЛЬНОСТИ
}

\begin{abstract}
Статья посвящена рассмотрению вариантов структуры экономической безопасности. Авторами проанализированы составляющие экономической безопасности государства, регламентированные нормативными документами Украины, а также те, которые выделяют в своих трудах ученые. Рассмотрены подходы к структурированию экономической безопасности по элементам, по функциям, по источникам возникновения угроз, по сторонам экономических процессов. Авторами предложено в составе внешней подсистемы экономической безопасности выделить военную, исходя из значительного влияние военных событий на экономическое положение государства. Отмечено, что начиная с аннексии Крыма, развертывания гибридной войны В Донбассе, экономическая безопасность Украины перешла с антикризисной в безопасность В условиях военных конфликтов, поэтому уже невозможно отделять экономическую безопасность от военной. Авторы пришли к выводу, что каждая составляющая имеет большую значимость и заслуживает отдельных исследований. Однако эти исследования следует проводить системно, изучая взаимные влияния между составляющими экономической безопасности, а также между другими составляющими национальной безопасности государства в современной глобализированной и военно нестабильной среде.
\end{abstract}

Ключевые слова: экономическая безопасность; военная безопасность; национальные интересы; угрозы; военно-политическая нестабильность. 